\title{
Tutkimuksen painopisteessä seleenin ympäristö- ja terveysvaikutukset
}

Mervi M Seppänen ${ }^{1)}$, Nashmin Ebrahimi ${ }^{1)}$, Raimo Kauppila ${ }^{2)}$, Juha Kontturi ${ }^{1)}$, Päivi Ekholm ${ }^{3)}$, Anthony Owusu $^{1)}$ ja Helinä Hartikainen ${ }^{3)}$

${ }^{1)}$ Maataloustieteiden laitos, PL 27,00014 Helsingin yliopisto, etunimi.sukunimi@helsinki.fi, 2) Elintarvike- ja ympäristötieteiden laitos, PL 27, Helsingin yliopisto, etunimi.sukunimi@ helsinki.fi, ग) Yara Suomi Oy, Kotkaniemen tutkimusasema, Vihti, etunimi.sukunimi@yara.com

\section{Tiivistelmä}

Seleeni on ihmisille ja eläimille välttämätön hivenaine, jonka riittävä pitoisuus elintarvikkeissa ja rehuissa varmistetaan Suomessa lannoitteisiin tai rehuihin tehtävällä seleenilisäyksellä. Lannoitteissa seleeniä lisätään vuosittain 6-10 g/ha, josta muutama prosentti päätyy siemensadon mukana elintarvikeketjuun. Kasvien orgaanisilla seleeniyhdisteillä on havaittu olevan myös mm. kemoterapeuttisia vaikutuksia, mikä voi lisätä seleenilannoituksen kansanterveydellistä merkitystä. Kaikki maahan lisätty lannoiteselenaatti ei kuitenkaan siirry satotuotteisiin, vaan voi ajan myötä pelkistyä ja sitoutua kemiallisesti hiukkaspinnoille tai päätyä takaisin maahan kasvijätteiden mukana. Tässä tutkimuksessa selvitettiin seleenin kiertoa peltoekosysteemissä sekä arvokkaiden orgaanisten seleeniyhdisteiden kertymistä viljelykasvien ravinto-osiin. Tavoitteena on ollut arvioida pitkäaikaisen seleenilannoituksen ympäristö- ja terveysvaikutuksia sekä pohtia miten viljelykasvien lannoiteseleenin käytön tehokkuutta voitaisiin parantaa.

Vehnän, rypsin, rapsin, nurmiheinien ja sinimailasen seleeninottoa, kulkeutumista kasvissa sekä maahan jääneen seleenin määrää tutkittiin pelto- ja kasvihuonekokeissa. Lisäksi selvitettiin arvokkaiden orgaanisten seleeniyhdisteiden kertymistä rapsin lehtiin ja siemeniin. Sinimailasella seurattiin lisäksi seleenilisäyksen vaikutusta juurinystyröiden muodostumiseen ja typensidontaan.

Vehnä ja rapsi keräsivät pensomis- ja ruusukevaiheessa seleeniä tehokkaasti. Öljykasvit ottivat lannoiteseleenistä lehtiruusukevaiheessa 30 - 40\%, josta noin $20 \%$ siirrettiin siemeniin. Kasvukauden edetessä öljykasvien ja vehnän lehdissä ja varsissa pitoisuus aleni biomassan kertymisen myötä. Kaiken kaikkiaan lisätystä seleenistä poistui sadon mukana $2-4 \%$. Puintijätteessä merkittävä osa seleenistä jäi siemenkuoriin ja lituihin. Rapsin lehdissä ja siemenissä siitä oli $70-80 \%$ selenometioniiniä (SeMet). Syöpää estävää selenometioniiniselenokysteiiniä (SeMetSeKys) kertyi hetkellisesti lehtiin, mutta tuleentuneissa siemenissä sitä ei enää havaittu. Etenkin rouheeseen kertyi merkittäviä määriä SeMet:iä, joka parantaa rouheen ravitsemuksellista laatua kotieläinrehussa. Sinimailasella seleenilannoitus nosti aktiivisten juurinystyröiden määrää, mutta ei vaikuttanut kasvuun tai kasvin sisältämän typen määrään. Sen sijaan se nosti sinimailasen sokeri- ja tärkkelyspitoisuutta ja mahdollisesti sitä kautta edisti juurinystyröiden muodostumista. Lyhytaikaisessa kokeessa seleenin kertymistä maahan ei voitu todentaa.

\section{Avainsanat}

Nurmiheinä, rapsi, rypsi, selenometioniini, selenometioniini-selenokysteiini, sinimailanen, vehnä 


\section{Johdanto}

Seleeni (Se) on ihmisille ja eläimille välttämätön hivenaine, jonka puutos aiheuttaa lihasrappeumaa ja yleisen vastustuskyvyn alenemista. Suomessa seleenin puutosoireita, kuten luurankolihasten rappeumaa, todettiin nopeasti kasvavilla nuorilla eläimillä vielä 1970-luvulla. Seleeninpuutoksen syy oli maaperämme alhainen biosaatavan seleenin määrä ja siitä johtuva rehujen alhainen seleenipitoisuus. Vuodesta 1984 lähtien elintarvikkeiden ja rehujen seleenipitoisuus on varmistettu lisäämällä sitä lannoitteisiin (Hartikainen 2005).

Lannoiteseleenistä pieni osa päätyy viljelykasvin sato-osiin, mikä on herättänyt kysymyksiä sen kohtalosta peltoekosysteemissä. Viljelykasvilajin tiedetään vaikuttavan seleenioton tehokkuuteen, esimerkiksi öljykasvit ottavat seleeniä viljoja tehokkaammin. Tämä lisäksi öljykasvit pystyvät assimiloimaan pieniä selenoproteiinejä, joista osalla on todettu olevan syöpää estäviä vaikutuksia (Rayman 2008). Tässä tutkimuksessa selvitettiin kasvihuone- ja peltokokeissa vehnän, rypsin, nurmien ja sinimailasen seleeninottoa ja kulkeutumista kasvissa sekä puintijätteen, juurien ja maan sisältämän jäännösseleenin määrää. Samalla selvitettiin miten arvokkaita seleeniyhdisteitä kertyy kasvin lehtiin ja sato-osiin.

\section{Aineisto ja menetelmät}

Seleenin kiertoa tutkittiin yhteensä kuudessa peltokokeessa (Viikki ja Kotkaniemen tutkimusasema) ja neljässä kasvihuonekokeessa (Viikki). Peltokokeissa käytettiin joko 0, 6 tai 20 g Se ha ${ }^{-1}$, joista alhaisempi taso vastaa tavanomaista lannoitusta. Kasvihuonekokeissa käytetyt lannoitustasot on esitetty tuloksissa. Koekasveina peltokokeissa olivat rypsi, rapsi, vehnä ja timotei-nurminataseos, kasvihuonekokeissa rapsi ja sinimailanen. Kasvinäytteitä kerättiin eri kehitys- ja kasvuvaiheessa. Kasvinosien (lehdet, kellastuneet lehdet, varret, juuret, siemenet, lidut) tuore- ja kuiva-ainepainot sekä seleenipitoisuus määritettiin (Seppänen ym. 2010). Öljykasveilla tutkittiin orgaanisten seleeniyhdisteiden kertymistä lehtiin ja siemeniin HPLC-ICPMS perustuvan menetelmän avulla (Seppänen ym. 2010) ja niistä mitattiin seleeniä assimiloivien entsyymien (ATPS1-4- ATP sulfurylaasi, SMT-seleenimetyylitransferaasi) aktivoituminen kvantitatiivisella PCR-menetelmällä. Sinimailasista laskettiin lisäksi aktiivisten juurinystyröiden lukumäärä ja määritettiin kasvien typpi- ja hiilipitoisuus, sokereiden ja tärkkelyksen määrä sekä energia-aineenvaihdunnan avainentsyymin, fruktoosi 1,6-fosfataasin, aktiivisuus.

\section{Tulokset ja tulosten tarkastelu}

Peltokokeissa öljykasvit olivat ottaneet ruusukevaiheessa noin $30 \quad-40 \quad \%$ lisätystä lannoiteseleenistä, josta $15-20 \%$ kuljetettiin siemeniin. Kukinnan alkuun mennessä kasvin ottamasta seleenistä noin $36 \%$ oli juurissa, $15-20 \%$ vihreissä lehdissä ja varsissa ja $27 \%$ kellastuneissa lehdissä. Puintijätteen seleenipitoisuus oli suoraan verrannollinen lisäyksen määrään. Koko kasvin ottamasta seleenistä noin $30 \%$ jäi puintijätteen varsiin ja jopa $46 \%$ lituihin. Vehnällä kasvin sisäistä seleenikiertoa ei kasvukauden aikana havaittu, mutta myös sillä merkittävä osa seleenistä jäi varteen ja siemenkuoriin. Alustavat tulokset nurmiheinillä viittaavat siihen, että sadonkorjuuvaiheessa seleeni on jakautunut melko tasaisesti maanpäällisten osien ja juurten välillä.

Seleenilannoituksella ei ole jälkivaikutusta seuraavana vuonna ja siksi elintarvikkeiden ja rehujen seleenipitoisuus on varmistettava joka vuosi lannoituksella. Merkittävä osa seleenistä jää puintijätteeseen, mikä lisää maan orgaanisen aineen sisältämän seleenin määrää. Viljelykasvin seleeninkuljetuksen tehostaminen onkin avainasemassa haettaessa ympäristöystävällisempiä tapoja seleenirikastuksen toteuttamiseksi. 
(A)

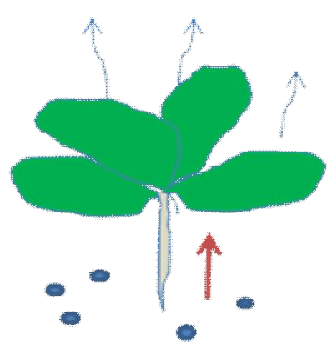

(B)

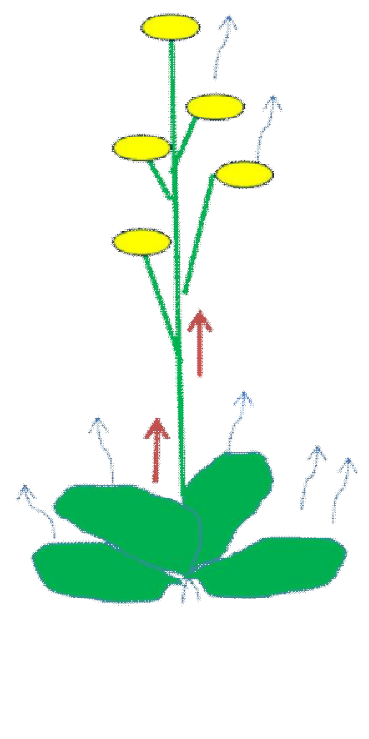

(C)

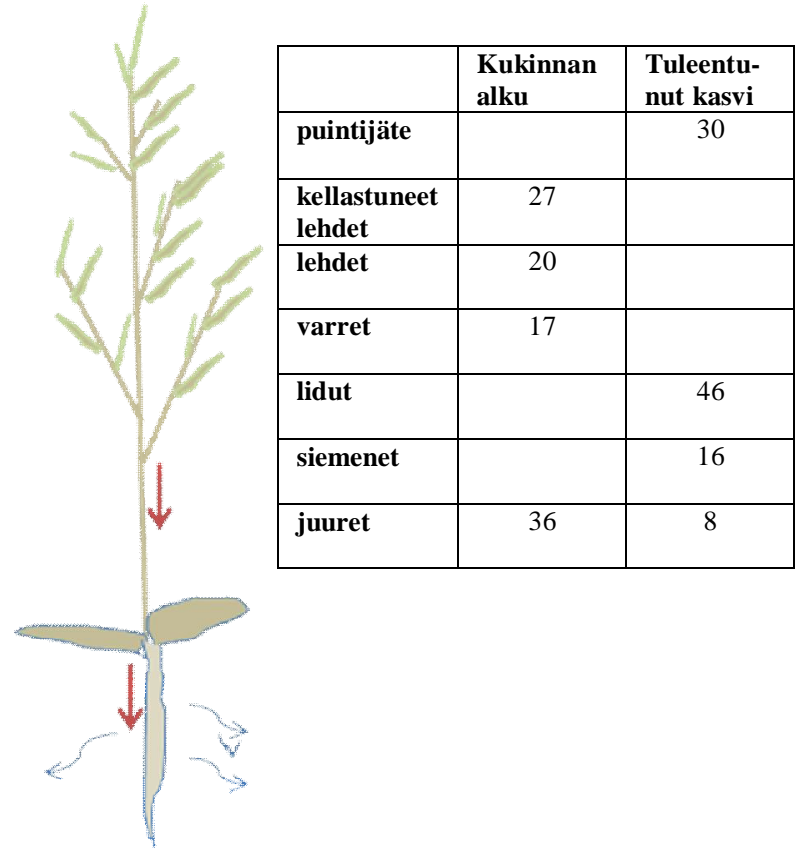

Kuva 1. Öljykasvin sisäinen seleenikierto. Öljykasvit ottavat lannoiteseleeniä tehokkaasti lehtiruusukkeeseen, josta se kuljetetaan muodostuviin siemeniin ja kasvukauden lopulla myös juuriin. Taulukossa esitetään kasvin sisältämän seleenin jakautuminen (\% kokonaisseleenistä) eri kasvinosien välillä.

Brassica-suvun lajit tunnetaan niiden kyvystä muuntaa seleeniä bioaktiivisiksi yhdisteiksi, kuten selenometioniini-selenokysteiiniksi (SeMetSeKys), jolla on havaittu kemoterapeuttisia ominaisuuksia (Rayman 2008). Kasvihuone- ja peltokokeissa mitattiin arvokkaiden orgaanisten seleeniyhdisteiden kertymistä lehtiin ja korjattuun siemensatoon. Seleenilisäyksen jälkeen SeMetSeKys-synteesistä vastaava $S M T$-geeni aktivoitui nopeasti ja SeMetSeKys:iä kertyi lehtiin. Rapsi luokitellaan seleeninoton perusteella niin kutsuttuihin sekundäärisiin kerääjäkasveihin, mikä näkyi rapsikasvuston-tässä kokeessa vehnää korkeampina seleenipitoisuuksina. Varsinaiset seleenin kerääjäkasvit, kuten Astragalus bisulcatus, assimiloivat lisäksi korkeita pitoisuuksia SeMetSeCys (White ja Broadley 2009). SMT-geenin rakenne poikkeaa ei-kerääjäkasvien ja kerääjäkasvien välillä, mikä vaikuttaa SeMetSeKys:in kertymiseen (Sors ym. 2009). Rapsin SMT-geenisekvenssi oli samanlainen kuin ei-kerääjäkasveilla, mikä selittää verrattain alhaista SeMetSeKys-synteesiä. Seleenilisäys aktivoi myös selenometioniini-(SeMet)-synteesin; selenaatti muunnettiin vaiheittain orgaanisiksi seleeniyhdisteiksi, etupäässä SeMet:ksi. Siemenissä ja valkuaisrikkaassa rouheessa $70-80 \%$ seleenistä oli SeMet:iä, joka teki rouheesta arvokkaan orgaanisen seleenin lähteen.

Kasvihuoneella tehdyissä kokeissa seleeni lisäsi aktiivisten juurinystyröiden määrää ja painoa sinimailasella, mutta ei vaikuttanut merkittävästi kuiva-aineen kertymiseen tai typen määrän kasvissa. Sen sijaan seleenikäsittely nosti sokeri- ja tärkkelyspitoisuutta ja todennäköisesti edisti parantuneen energiatalouden kautta juurinystyröiden muodostumista.

\section{Johtopäätökset}

Kasvukauden alussa oli vehnän ja rapsin lehtien seleenipitoisuus korkea ja se laimeni biomassa kertymisen myötä erityisesti vehnällä. Merkittävä osa seleenistä jäi olkiin ja varsiin sekä siemenkuoriin ja lituihin. Rapsilla osa seleenistä kuljetettiin kukinnan aikana juuriin ja 
mahdollisesti sitä kautta maahan. Maan seleenipitoisuuteen lyhytaikaisella kokeella ei ollut vielä vaikutusta. Viljelykasvien väliset erot niiden seleeninotossa ja assimilaatiossa voitaneen hyödyntää lannoituskäytänteitä suunniteltaessa. Seleenilannoituksella oli positiivisia vaikutuksia öljykasvien rouheen laatuun, sillä se mahdollisti arvokkaan SeMet:n kertymisen siemeniin. Rapsilla terveysvaikutteista SeMetSeKys kertyi lehtiin, mutta siemenissä tärkein orgaaninen seleeniyhdiste oli SeMet.

\section{Kirjallisuus}

Hartikainen, H. 2005. Biogeochemistry of selenium and its impact on food chain quality and human health. Journal of Trace Elements Medical Biololgy 18:309-318.

Pilon-Smits, E.A.H., Quinn, C.F., Tapken, W., Malagoli, M., Schiavon, M. 2009. Physiological functions of beneficial elements. Current Opinions Plant Biology 12:267-274

Rayman, M. 2008. Food-chain selenium and human health: emphases on intake. British Journal of Nutrition 100:254-268.

Seppänen, M.M., Kontturi, J., Lopez Heras, I., Madrid, Y., Camara, C., Hartikainen, H. 2010. Agronomic biofortification of Brassica with Selenium - enrichment of SeMet and its identification in Brassica seeds and meal. Plant and Soil 337:273-283

Sors, T,G., Martin, C.P., Salt, D.E. 2009. Characterization of selenocysteine methyltransferases from Astragalus species with contrasting selenium accumulation capacity. Plant Journal 59:110-122. 